\title{
Identity drama: anti-and postcolonial discourse (based on Leslie Marmon Silko's short stories "Lullaby" and Volodymyr Danylenko's "Thunderstorms over Turovets")
}

\section{Olena Buriak, Oksana Holnyk, Mariia Lavrusenko, Oleksandra Tsepa, Oksana Vechirko}

\begin{abstract}
The article highlights the artistic specifics of the anti- and postcolonial discourse of the stories "Lullaby" by the American writer of Indian origin Leslie Marmon Silko and "Thunderstorms over Turovets" by the Ukrainian novelist Volodymyr Danylenko. Through the prism of the conflict "globalized world - ecumenical world" the peculiarities of the embodiment of the drama of national self-awareness are considered.
\end{abstract}

Keywords: anticolonialism, postcolonialism, conflict, crisis, national identity, psychological trauma, alienation.

Received: 07.12.2020 Accepted: 11.01.2021 $\quad$ Published: 03.02.2021

\section{Introduction}

The anti-colonial and post-colonial discourse of modern literature is an objective and logical manifestation in the second half of the twentieth and twenty-first centuries of existentialism as a philosophical and aesthetic system. This is evidenced by the study of theoretical research of Ukrainian scientists (Marko Pavlyshyn [12], Tamara Hundorova [16], Olena Yurchuk [22], etc.), as well as foreign researchers, starting with the cult work of Edward Said [4] and ending with the studies of Bill Ashcroft, Gareth Griffiths, Helen Tiffin [1], Brennan, K. Brisley [2], Alexandra Effe [5], Alexander Fyfe [6], Annie Gagiano [7], Chris Langlois [8], Jonathan Lench [9], Sirsha Nandi [10], Pramod K. Nayar [11], Christopher Taylor [13], Ryan Topper [14] and others.

The vast majority of scholars agree that the anti-colonial is closely interrelated with the postcolonial. Moreover, it is partly difficult to distinguish the boundaries between these discourses; the ideological-semantic and conceptual-aesthetic boundary between them is so shaky.

\section{Materials and methods}

Creating a bibliometric study of postcolonial studies from 1900 to 2017, a team of scientists (Dr. Hammad Mushtaq, Khurshid Ahmad, Muhammad Rafi) made several important generalizations on the definition of postcolonial discourse, its so-called ideological and aesthetic markers. In particular, the scientists noted: "Postcolonialism is a significant field of literary studies that refers to the study of the literary, social and cultural heritage of colonial and imperial powers and focuses on the impact of hegemonic control and exploitation of the people who were colonized" [3, p.207].

According to the researchers, the term "postcolonialism" appeared in the late 1970s. The twentieth century and its essence is reduced to the presentation of cultural, racial, ethnic and social identity of a man in modern history. While American and European literary critics believe that "postcolonial literature mainly focuses on the outcomes of the interaction between European colonial powers and the people of the countries they colonized" [3, p. 208], Ukrainian scientists tend to consider this discourse through the prism of national - totalitarian conflicts, external and internal colonization. However, whatever format scientists choose when identifying key aspects of postcolonial literature, they all agree on one thing - the identity and the struggle for this identity of a person who belongs to the colonized peoples.

However, regardless of the nature the conflict unfolds in the space of culture and correlates with the problem of national and cultural identity. This approach is one of the options for implementing the general philosophical problem of modern society - the problem of personalization of the individual, and more broadly - spirituality. According to the Ukrainian philosopher Serhii Krymskyi, personalization is a way out of the tragic collision of today, when civilization makes people gods (taking into consideration the level of technical development) before they become worthy of human status [18, p. 347]. This is the basic collision of humanism and existentialism. The way to overcome it, according to the philosopher, testifies to the spiritual progress of a man. It is possible under the condition of personalization, the key to which is the acquisition of identity primarily through the discovery of their national self, because "the 
disclosure of national life is combined in the spiritual maxims of the XXI century with actualization of universal values of world civilization" [18, p. 350].

\section{Results}

National archetypes are carriers of transpersonal phenomena in the human mentality. They determine the spiritual sovereignty of the individual. In the stories of Leslie Marmon Silko "Lullaby" and Volodymyr Danylenko "Thunderstorms over Turovets" they are represented through the dreams of heroes, songs, rituals, subconscious strivings and intentions, memories, symbols, the source of which is the archaic (premodern) existence of the people.

The problem of identity defines a pervasive, immanent conflict that not only permeates but also organizes works with postcolonial pathos. It is a question of opposition of "alien" and "own". It can be both implicit (unconscious, intuitively felt) and explicit (conscious). The following analysis of the creative presentations of this conflict in the work of the American writer Leslie Marmon Silko and the Ukrainian writer Volodymyr Danylenko clearly demonstrates this.

As a rule, either peoples colonized or those who fall under the assimilative influence of global cultures, get a traumatic experience of replacing national existential codes with foreign ones. This is not only the cause of internal drama, but also the impetus for the restoration (restructuring) of their identity, integrity.

The analysis of the works of two writers proposed in the article - an American with Indian roots and a Ukrainian with a traumatic experience of denationalization - presents an extrapolation of the conflict between the globalized, multicultural and urbanized world and the national, ecumenical world.

\section{Discussion}

Anti- and postcolonial pathos can be clearly seen in the works of English-speaking Indian writer Leslie Marmon Silko, who after the publication of the novel "Ceremony" (1977) became "one of the key figures of the so-called "Indian Renaissance" 60-70's of the twentieth century" [19]. The worldview of the original artistic style is its cultural marginality, due to its specific identity: Silko's parents are Mexican and European, she is a quarter Indian. However, despite this "multicultural" genetic code, the artist's short stories clearly show the manifestation of Indian origins (a collection of rhythmic miniature stories and "Storyteller" (1981), novels "Almanac of the Dead" (1991), "Gardens in the Dunes" (1999) and others).

One of the brightest proofs of this is the touching story "Lullaby", in which the main character is also a narrator.

Native American Aya lives in a hostile civilized American world. Loneliness, social and mental alienation are recreated in a dramatic symbolic image at the end of the story - a woman and her crazy husband Chato are sitting in a blizzard, wrapped in a blanket. The existentialist ambiguity of this picture - small people mutilated by life freeze on the winter road, feeling that the Ice Calm descends to them from the night sky - emphasizes the idea of insecurity and doom of the individual in an alien environment. As the last intuitive resistance of Aya against erasing her in this world, as an assertion of her identity, joining the traditions of the genus a woman's voice singing an Indian lullaby is heard.

The brilliant pointe is psychologically justified: in the face of death a person is always real, and Aya's authenticity is manifested primarily through her national identity. Indians perceive death not as the end of life, but a change in the state of existence: "time is perceived as an infinite series of closed rings, because life is subject to infinite change of cycles of nature" [21, p. 187]. Just as nature falls asleep in winter, so, according to the Indians, a man falls asleep to wake up after a while in a new existential form.

Poetically recreated figurative mythological bloodline in the song: Mother Earth, Father Heaven, Wind Brother, Rainbow Sister embodies the life principle of the Indians of unity, harmony of man and nature, man and space.

The marginality of the main character creates an inevitable internal conflict, which is exacerbated by external - traumatic collision with the masters of life, the descendants of the colonizers.

External socio-historical conflict is manifested in the oppression of the Indians by the metropolis, moral humiliation, violation of their rights to full existence.

Aya and Chato moved to Colorado, where the man worked hard on the "white master's" ranch, [20] but the family was destitute, living in ruins. When Chato grew old, his master and his wife even evicted him from this apartment to house new workers.

Aya dreams of returning to her home with an earthen roof and walls made of folded stones, from which she left with her husband for a new life. This home can hardly be called more comfortable, but it was the heart of family comfort and happiness in their homeland.

The attempt of Aya's husband to adapt to the new world by learning English was unsuccessful. The fact that he taught his wife to sign in English played a fatal role: not being able to read, Aya signed an 
agreement which allowed to remove from the family two younger children - Ella, who had barely learned to walk, and a little older Danny.

The instruction of the ancient Indians, the ancestral wisdom gained through painful historical experience is confirmed: do not adopt the language or customs of whites because it threatens trouble.

The new world deprives the most precious thing - children: "doctors looked at them like a lizard on a fly" [20] and forcibly removed them from the mother. After the death of his eldest son, who served in the army, it was a disaster. Doctors dressed in a khaki uniform, who are obliged to help, embody the threat, they are an image of an aggressive military society that destroys and ruins everything that goes beyond its norms and canons. Another blow for Aya is the psychological and cultural alienation of the children: when they meet, the daughter does not recognize the mother for a long time, and the son forgets his native language and mixes English words with Navajo words.

There is an attempt of the woman to survive, to preserve her self through conscious and unconscious assertion of her identity. The Indian identity of the heroine is manifested on different levels and in different ways.

Since the main character is a subtle emotional nature, her national self is manifested primarily at such levels of worldview as attitude and world perception, formed under the influence of Indian mentality, culture and life.

The phenomena of nature are comprehended through the prism of the existence of the Indians: watching the snowfall, Aya compares it with tufts of sheared sheep's wool. Thus, through the worldview of the heroine, the image of weaving - an ancient Indian craft - is presented. Listening to the wind, the woman hears a song of good spirits from Indian folklore. Interestingly, the audiovisual imaginary images compensate for the heroine's lack of the Indian world, thus restoring her identity.

The main way to actualize the Indian essence of the heroine is memory - the path to her roots, to herself: "Memories gave birth to peace. She was no longer cold."[20] Memory harmonizes Aya's state, because she "remembers" herself as real, she self-renews, becomes herself. The content of the heroine's visions is determined by the Indian image-emotional matrix.

The associative series that arises in a woman's mind is "snow - weaving - family." The heroine sees herself as a child when she combed the wool for spinning, remembers her mother weaving on a loom, her grandmother who winds a thread on a spindle. A woman intuitively seeks support, protection, establishing a connection with the past, placing herself in the context of the Indian family - the source of her life force, spiritual inspiration.

Her past life in an organic Indian environment for the heroine is perceived by her as a personal "golden" time, where she felt inner harmony.

The situation of psychological discomfort is expressed through the subject artistic details, which at the micro level in the emotional dimension "native world - another world" actualize the key opposition "Indians - Americans" (read: "colonized - colonizers").

Aya is happy to remember how warm it was under her mother's blankets, wrapped in an army blanket brought by her son, and looking at the boots with iron buckles, she remembers the deer-skin wraps over the moose-skin moccasins.

A special place in a woman's soul belongs to the memory of the birth of the firstborn - an emotionally colored congratulatory picture-extravaganza, where the original, instinctive manifestation of the female essence combined with the pristine beauty of nature. The time of the boy's birth - summer morning became his name, poetic, filled with maternal tenderness and admiration. In a new, alien world, the son became an ordinary Jimmy. This change of name symbolizes the leveling of its former uniqueness and the mother's desire to adapt, to fit the child into another sphere of life, which eventually kills him (soldier Jimmy dies in a plane crash). It is noteworthy that the father does not insist on the return of his son's body. Perhaps he feels that in a foreign land a dead young man will not find peace, or perhaps he realistically assesses the state of affairs, realizing that no one will bother to search for a dead Indian.

Aya, trained to suppress her emotions in a pragmatic American environment, reacts restrainedly to her son's death: "She did not cry, but inside she was in pain from anger" [20]. The internal conflict reaches its apogee: the hostile world has taken away the most precious thing, and she has no strength to fight this monster, just as she has no hope of understanding her pain, her grief. A woman involuntarily accepts the strict laws of survival in a pragmatic society: she mourns her son later, when her husband injured his leg and could not work, and there was no one to help.

The Indian family's efforts to fit into American society ended tragically: psychologically traumatized Aya, half-mad crippled Chato die, the fates of their children Ella and Tony are mutilated, because they are torn from the bosom of the family, the bosom of their culture, their eldest son Jimmy died. 
The works of the modern Ukrainian writer Volodymyr Danylenko also have a postcolonial sounding. Born in the 1960s, the artist experienced the peculiarities of life in Ukraine, integrated into the Soviet Union, led by the dominant Russian nation. The search for one's own identity as an antithesis to being under a conqueror can be read in his novel "Confession of the Jura Samoilovych ", the novel "Cage for oriole", stories "Thunderstorms over Turovets", "Mushroom Scream", "Football in Turov" and others, the author depicts the history of the village of Turovets for several centuries, building the artistic myth of his small homeland.

It is necessary to note that if Leslie Marmon Silko's prose has a clear anti- and postcolonial orientation, as it is written in the language of the colonizer and sounds like a tragedy of people entering the world of foreign culture, overcoming internal resistance, the epic texts of Ukrainian author Volodymyr Danylenko are written in his native language, however in their subtext awareness of the drama of human existence on their own land, but in a foreign country is clearly visible. In the works of the writer there is a dialogue with a contemporary, a call to find their origins to build personal and national future. An example of this is the autobiographical story "Thunderstorms over Turovets" from the book of the same name by the writer, marked as "family chronicles".

In his work Volodymyr Danylenko raises the issue of a person's search for his own identity. The appeal to the true self, to his beginning is realized in the story through the creation of a family myth, rooted in Ukrainian national customs and traditions.

Researchers claim that the main means of prose writing by Volodymyr Danylenko is "an internal monologue that most accurately reproduces the immediate mental processes in the extreme situation of existential experiences" [15]. The story in "Thunderstorms over Turovets" also takes the form of an internal monologue-memory of the hero about a woman who helped him refute the slander of fellow villagers by taking rain from people. This story has formed in him a powerful inner core, faith in himself and his family, this unity will provide confidence in the future. We emphasize that similar rhetoric can be read in Volodymyr Danylenko's story "Mushroom Scream".

The hero and narrator of "Thunderstorm over Turovets" is a teenage boy who learns the science of life through communication with his grandmother Marina. He feels happy and protected in his family; because only a woman believes that her grandson is telling the truth. Through the narrator's memoirs, Volodymyr Danylenko creates a new myth, written in accordance with the realities of the twentieth century, about the status of women in the Ukrainian family. The heroine of the work embodies the features of the archetype of the Mother-Guardian, who stands at the head of the family and is ready to protect everyone in a difficult situation. The emphasis on her status in the work is a call to look into the matriarchal past of our land, the traditions of which have been preserved in national folklore, because, according to pre-Christian beliefs, a woman is a universe that unites all generations.

The grandson tries to understand what nourishes the head of the family, what gives her extraordinary strength. In the descriptions of Marina's grandmother, Volodymyr Danylenko combines the real, the genuine, the domestc with the fantastic, imaginary, mysterious, rooted in Ukrainian mythological thinking.

The heroine appears as an ordinary woman who takes care of her household, knows how to cook deliciously and loves her family. However, the portrait details, which the narrator emphasizes, indicate the unusual nature of the woman. The grandson mentions that the woman had black hair, as well as "piercing black eyes, and no one could stand her gaze... It seemed to me that the woman sees through every person" [17, p. 353]. Grandmother Marina's supernatural abilities are closely connected with her native land, with those elements that are cult for Ukrainians. When people in the village insulted her grandson, the woman resorted to fantastic sorcery - she collected clouds in a jug and hid them for several weeks, which deprived people of rain. Water and fire came to the defense of the family. The culmination of the heroine's magical actions will be rain with thunder, which will fall on Turovets for several weeks as punishment.

The soothsayer grandmother Marina is in complete harmony with nature. The heroine dedicates her grandson to the secrets of her extraordinary strength. They are in the ability to hear, understand and love their homeland. A woman teaches such wisdom to a teenager at the moment of psychological trauma. The subtext of the work affirms the idea of the invincibility of the national spirit, because it makes a person strong, and therefore free and ready to overcome obstacles in life.

The myth of Gardian in Volodymyr Danylenko's story "Thunderstorms over Turovets" is modernized and filled with new meaning. The heroine is depicted as a universal connoisseur of not only verbal but also literary words. Grandmother Marina's conclusion: "The world is hidden in the living word, and in the written word - only its shadow" [17, p. 355], - has a special meaning. There is a hidden author's opinion that the written word does not always correspond to the truth of life. The "written word" in the heroine's warning can be commented on as the word of a stranger, whose mission is to instill in a person 
other values, to emphasize the secondary nature of his national origin. This subtextual meaning emphasizes the anti- and postcolonial pathos of the work, because through the narrator the author motivates recipients to learn about their origins, whose roots are in the unshaded thought from the outside of folk wisdom passed down from generation to generation. Grandma Marina's speech is also noticeable. It is full of dialect words. In this way, the author demonstrates the connection between the family myth that the narrator creates about his grandmother and the national myth, the core of which is the woman-Guardian.

The postcolonial discourse in Volodymyr Danylenko's story "Thunderstorms over Turovets" can be traced in the antithesis of the harmony of the parental home and the discomfort of the street and society. The palette of the narrator's feelings related to being outside the family circle has a negative context. The boy receives a psychological trauma, because his truth (read - identity) is not recognized by others. In his village, in his native land, he finds himself in a situation of social alienation. The psychological trauma experienced by the hero is supposedly typical, because many teenagers go through a similar period of self-affirmation. However, the native-foreign village pushes out the one who defends himself as real, true, and this moment acquires a symbolic sound in the work. A parallel is drawn with the long centuries of existence of Ukrainians in colonial dependence on neighboring nations, when a person with national convictions was the enemy.

Note that in depicting the behavior of fellow villagers who falsely implicated the narrator, there is also an anti-colonial context. The heroes do not seek the truth, but reluctantly accept lies, which we believe is a typical feature of people who have been deprived of the right to think and seek the truth in times of colonial dependence.

Thus, Volodymyr Danylenko's story "Thunderstorms over Turovets" has anti- and postcolonial content. The postcolonial is manifested in the neo-mythological search of the hero of his identity - the creation of a family myth about a woman-Guardian. Anti-colonial is revealed in the condemnation of the actions of people deprived of their freedom, the desire to think and seek the truth. They are positioned as an alien, hostile, uncomfortable world, opposed to the harmony of the national family.

Note that Volodymyr Danylenko's story "Thunderstorms over Turovets", unlike Leslie Marmon Silko's "Lullaby", has an optimistic ending. It depicts the process of forming a strong hero, rooted in national life. In this way, the writer affirms the hope that Ukrainians will overcome colonial thinking and behavior.

\section{Conclusions}

Thus, the anti-colonial and post-colonial discourses of modern literature in terms of ideological and semantic and conceptual and aesthetic are correlated.

Works with postcolonial pathos focus on the understanding of identity, the struggle for which is both implicit (unconscious, intuitively felt) and explicit (conscious). Organic in this context is the expression of the conflict between the globalized, multicultural and urbanized world and the world of the national, ecumenical.

The "Lullaby" by the American writer Leslie Marmon Silko tells the tragedy of people who enter the world of another culture. In "Thunderstorms over Turovets" by Ukrainian artist Volodymyr Danylenko we have the drama of human existence on our own land, but in a foreign country. In the mentioned texts the opposition of "foreign" and "own" is artistically encoded in national archetypes, peculiarly represented through the dreams of heroes, memories, subconscious urges and intentions, songs, rituals, etc.

\section{References}

1. Ashcroft, B. (2007). Postcolonial Studies: The Key Concepts / B. Ashcroft, G. Griffths, H. Tiffin. 2nd ed. L. : Routledge. $292 \mathrm{p}$.

2. Brennan K. B. (2019). Parallel Visions, Confluent Worlds: Five Comparative Postcolonial Studies of Caribbean and Irish Novels in English, 1925-1965. Cambridge journal of postcolonial literature inquiry. vol. 6, no 1, pp. 156-157. doi: 10.1017/pli.2018.33

3. Dr. Hammad Mushtaq, Khurshid Ahmad, Muhammad Rafi. (2018). Analysis of Postcolonialism Literature: A Bibliometric Study from 1900 to 2017. Qualitative and Quantitative Methods in Libraries (QQML) 7: P.205-229.

4. Edward W. Said (1978). Orientalism. New York: Pantheon.

5. Effe A. (2020). Postcolonial criticism and cognitive literary studies: A new formalist approach to Antjie Krog's Country of My Skull. Journal of postcolonsal writing. vol. 56, no. 1, pp. 97-109. doi: 10.1080/17449855.2019.1702084 
6. Fyfe A. (2019). The Archival Politics of the Postcolonial Writer's Collection: A Case Study in Literary Value and Amos Tutuola. Ariel-A review of international English literature. vol. 50, no. 2-3, pp. 137161.doi: 10.1353 /ari.2019.0017

7. Gagiano A. (2019). Postcolonial Illuminations of Past Betrayals in Tan's The Gift of Rain and Owuor's Dust. Wenshan review of literature and culture, vol.12, no. 2, pp.1-27. doi: 10.30395/WSR.201906_12(2).0001

8. Langlois C. (2020). "A Punishment of Dreams": Reading Rushdie's The Satanic Verses after Orientalism. Ariel-A review of international English literature. vol. 51, no. 1, pp. 31-56.

9. Lench J. (2019). After Said: Postcolonial Literary Studies in the Twenty-First Century. English studies. vol. 100, no. 8, pp. 1019-1022. doi: 10.1080/0013838X.2019.1676016

10. Nandi S. (2018). Africa's Narrative Geographies: Charting the Intersections of Geocriticism and Postcolonial Studies. Transnational literature. vol. 11, no. 1, pp. 1-3.

11. Nayar P.K. (2018). Postcolonial Graphic Lifewriting: Finding My Way and the Subaltern Public Sphere. Narrative. vol. 26, no. 3, pp. 339-357. doi: 10.1353/nar.2018.0017

12. Pavlyshyn, M. (1992). "Post-colonial Features in Contemporary Ukrainian Culture." Australian Slavonic and East European Studies 6.2. P. 41-55.

13. Taylor C. (2018). Postcolonial Studies and the Specter of Misplaced Polemics against Postcolonial Theory: A Review of the Chibber Debate. Cambridge journal of postcolonial literature inquiry. vol. 5, no. 2, pp. 234-249. doi: $10.1017 /$ pli.2018.2

14. Topper R. (2019). Trauma and the African Animist Imaginary in Aminatta Forna's The Memory of Love and Delia Jarrett-Macauley's Moses, Citizen, and Me. English language notes. vol. 57, no. 2, pp. 86-98. doi: 10.1215/00138282-7716171

15. Honcharuk, M. (2015, sichen). Novyi heroi, shcho ziavyvsia na ruinakh imperii [A new hero who appeared on the ruins of the empire] [in Ukrainian]. URL: http://bukvoid.com.ua/reviews/books/2015/01/01/132757.html

16. Hundorova, T. (2013). Tranzytna kultura. Symptomy postkolonialnoi travmy: statti ta esei [Transit culture. Symptoms of postcolonial trauma: articles and essays]. Kyiv: Hrani-T [in Ukrainian].

17. Danylenko, V. (2014). Hrozy nad Turovtsem. Rodynni khroniky [Thunderstorms over Turovts. Family chronicle]. Lviv: Piramida [in Ukrainian].

18. Krymskyi, S. (2008). Pid syhnaturoiu Sofii [Under the signature of Sophia]. Kyiv: Vydavnychyi dim «Kyievo-Mohylianska akademiia» [in Ukrainian].

19. Kupriian, O. (2011, zhovten). Ta, yaka rozpovidaie istorii [The one that tells stories]. LitAktsent [in Ukrainian]. URL: http://litakcent.com/2011/10/06/ta-jaka-rozpovidaje-istoriji/

20. Leslie Marmon Sylko. (2018, lypen). Kolybelnaya [Lullaby] [in Russian]. URL: https://mdeksperiment.org/post/20180720-lesli-marmon-silko-kolybelnaya

21. Shostak, O. H. (2004). Problemy interpretatsii literaturnoi tvorchosti Lesli Marmon Silko [Problems of interpretation of Leslie Marmon Silko's literary work]. Mova i kultura - Language and Culture (Vols.7/1), (pp.184-190). Kyiv [in Ukrainian].

22. Yurchuk, O. (2013). U tini imperii. Ukrainska literatura u svitli postkolonialnoi teorii [In the shadow of the empire. Ukrainian literature in the light of postcolonial theory] Kyiv: Akademiia [in Ukrainian]. 